\title{
Phlebotomines (Diptera, Psychodidae) in the Speleological Province of the Ribeira Valley: 2. Parque Estadual do Alto Ribeira (PETAR), São Paulo State, Brazil
}

\author{
Eunice A. B. Galati ${ }^{1}$, Ana Maria Marassá2, Rute Maria Gonçalves-Andrade ${ }^{3}$, Cleide Aschenbrenner Consales ${ }^{4}$ \\ \& Edna Fátima Maria Bueno ${ }^{1}$
}

Departamento de Epidemiologia, Faculdade de Saúde Pública, Universidade de São Paulo. Av. Dr. Arnaldo 715, 01246-904 São Paulo-SP, Brazil. egalati@ usp.br

${ }^{2}$ Post-graduate student of the Faculdade de Saúde Pública and Secção de Parasitoses Sistêmicas, Instituto Adolpho Lutz, Av. Dr. Arnaldo 355; $01246-904$ São Paulo-SP, Brazil. anamarassa@usp.br

${ }^{3}$ Laboratório de Imunoquímica, Instituto Butantan, Av. Vital Brasil 1500, 05508-900 São Paulo-SP, Brazil. rutemgdeandrade@butantan.gov.br

${ }^{4}$ Instituto Pasteur, Av. Paulista 393, 01311-000 São Paulo-SP, Brazil. cleide135@yahoo.com.br

\begin{abstract}
Phlebotomines (Diptera, Psychodidae) in the Speleological Province of the Ribeira Valley: 2. Parque Estadual do Alto Ribeira (PETAR), São Paulo State, Brazil. The Parque Estadual do Alto Ribeira (PETAR) with about 250 caves, in an Atlantic forest reserve, is an important ecotourist attraction in the Ribeira Valley, an endemic area of American cutaneous leishmaniasis (ACL). With the purpose of investigating Leishmania vector species bothersome to humans the sandfly fauna was identified and some of its ecological aspects in the Santana nucleus, captures were undertaken monthly with automatic light traps in 11 ecotopes, including caves, forests, a camping site and domiciliary environments, and on black and white Shannon traps, from January/2001 to December/2002. A total of 2,449 sandflies representing 21 species were captured. The highest values of abundance obtained in the captures with automatic light traps were for Psathyromyia pascalei and Psychodopygus ayrozai. A total of 107 specimens representing 13 species were captured on black (12 species) and white (6 species) Shannon traps set simultaneously. Psychodopygus geniculatus females predominated on the black (43.75\%), and Psathyromyia lanei and Ps. ayrozai equally (32.4\%) on the white. Nyssomyia intermedia and Nyssomyia neivai, both implicated in the transmission of ACL in the Brazilian Southeastern region, were also captured. $N y$. intermedia predominated in the open camping area. Low frequencies of phlebotomines were observed in the caves, where Evandromyia edwardsi predominated Lutzomyia longipalpis, the main vector of the American visceral leishmaniasis, was aslo present. This is its most southernly reported occurrence in the Atlantic forest.
\end{abstract}

KEYWORDS. Caves; ecology; leishmaniasis; sandfly; vectors.

RESUMO. Flebotomíneos (Diptera, Psychodidae) na província Espeleológica do Vale do Ribeira. 2: Parque Estadual Turístico do Alto Ribeira (PETAR), São Paulo, Brasil. O Parque Estadual Turístico do Alto Ribeira, com cerca de 250 cavernas, situado em reserva de floresta Atlântica, é uma importante atração turística na região do Vale do Ribeira, onde a leishmaniose tegumentar americana (LTA) é endêmica. Com o objetivo de investigar as espécies incômodas ao homem e/ou implicadas na transmissão de Leishmania, identificou-se a fauna flebotomínea e alguns aspectos ecológicos de suas populações no núcleo da caverna Santana. Mensalmente, de janeiro/2001 a dezembro/2002, foram realizadas capturas com armadilhas automáticas luminosas em 11 ecótopos, incluindo cavernas, florestas, área de camping e ambientes domiciliares, e com armadilhas de Shannon em mata. No total capturouse 2.449 flebotomíneos, representando 21 espécies. Nas capturas com armadilhas automáticas luminosas, Psathyromyia pascalei e Psychodopygus ayrozai foram as mais abundantes. Com as armadilhas de Shannon branca e preta instaladas simultaneamente foram capturados 107 espécimes, representando 13 espécies, na preta (12 espécies) e na branca (6 espécies). Fêmeas de Psychodopygus geniculatus predominaram na preta $(43,75 \%)$, e Psathyromyia lanei e Ps. ayrozai, igualmente $(32,4 \%)$, na branca. Nyssomyia intermedia e Nyssomyia neivai, ambas implicadas na transmissão da LTA na região, também foram capturadas, Ny. intermedia, a $6^{\mathrm{a}}$ mais abundante, predominou na área de camping aberto. Baixas freqüências de flebotomíneos foram observadas nas cavernas, onde Evandromyia edwardsi predominou. Destaca-se a captura de Lutzomyia longipalpis, principal vetor do agente da leishmaniose visceral americana, sendo o registro mais meridional da mata Alântica.

PALAVRAS-CHAVE. Cavernas; ecologia; flebotomíneos; leishmaniose; vetores.

A great concentration of carbonate karst areas, commonly favorable to the formation of caves, is to be found in the eastern half of Brazil, mainly in the states of Bahia, Minas Gerais and Goiás. Among the fourteen most extensive of them, with an area of about $11,900 \mathrm{~km}^{2}$ and noteworthy as containing the largest number of caves, is the rock formation of the Açungui group, in the Speleological Province of the Ribeira Valley, in southeastern Brazil, largely in the south of São Paulo State (Auler 2002). This province, located on the left bank of the Ribeira de Iguape river, is in great part situated on the Serra de Paranapiacaba, mainly in two forest reserves: the Upper Ribeira State Tourist Park - Parque Estadual Turístico do Alto Ribeira (PETAR), with about 250 registered caves, and the Intervalleys State Park - Parque Estadual Intervales (PEI) ( $\sim 80$ caves) (T. Gonçalves, pers. comm.). This great number of caves and the remnant of Atlantic forest have attracted many people interested in ecological tourism to these parks.

Caves are natural cavities in the subsoil that may be interconnected by subterranean spaces and most of the Açungui rock formations contain active drainage (Auler 
2002). Their communication with the external environment may occur through sinkholes where the water disappears underground, or openings caused by caving-in (Dessen $e t$ al . 1980). The cave environments present smaller daily variation of temperature and relative humidity than the external ones; the annual average of the latter being almost 100\% (Boggiani et al. 2007). Depending on the size of the cave, three zones may be distinguished: a twilight zone, close to the entrance, an intermediate one of complete darkness and variable temperature and that in the deepest areas, completely dark and of constant temperature (Poulson \& White 1969). The foods present in the cave soil originate from animal droppings, vegetal debris, remains of arthropods and of other organisms found in aqueous solutions and moist or dry soil. The floor material consists of fragmented sediments, sand, silt and clay, such as may result from the fall of rock fragments from the cave roof and walls (Poulson \& White 1969) and in some areas from the influx of material brought in by the rain.

Forests and caves are natural habitats of the phlebotomine sand flies (Diptera, Psychodidae) (Aguiar \& Medeiros 2003; Cipa Group 1999), females of which are haematophagous, biting mammals, birds and cold-blooded animals. Many of their species are also anthropophilic and beyond bothering humans by their painful bites, may transmit pathogens such as viruses, bacteria and Trypanosomatidae (Shaw et al. 2003) to people who enter these environments. Among the Trypanosomatidae, species of the genus Leishmania, having wild or synanthropic mammals as primary hosts and causing visceral, cutaneous or muco-cutaneous leishmaniases in humans, have received the special attention of public health organizations due to the increase in the incidence and expansion of these infections throughout Brazilian territory and the severity of some of the clinical forms of these diseases.

The region of the Ribeira Valley registered a total of 1,174 cutaneous leishmaniasis cases between 1998 and 2006, which gives an average annual coefficient of incidence of 47.71/100,000 inhabitants, one of the highest of the São Paulo state. This coefficient for Iporanga municipality where the greater part of the PETAR is situated is $152.9 / 100,000$ inhabitants (Cve 2007), one of the highest in the Ribeira Valley region.

Several studies on phlebotomines in forested and/or anthropic environments have been undertaken in the Ribeira Valley to investigate the vectors of cutaneous leishmaniasis (Forattini et al. 1976; Gomes et al. 1980, 1982, 1983, 1986, 1990; Gomes \& Galati 1987, 1989; Domingos et al. 1998; Taniguchi et al. 2002); but, as far as we know, no research has yet been published on the speleological province of this region. Thus, this project was carried out to investigate leishmaniasis agent vectors bothersome to humans in view of the use of this area for ecotourism, which may bring many susceptible people into contact with them, and to identify the phlebotomine fauna and describe some aspects of its behavior in some of the caves and also in the forested and anthropic environments of PEI (Galati et al. 2010) and PETAR. The present paper relates specifically to the sandfly fauna of the PETAR.

\section{MATERIAL AND METHODS}

Study area. The Parque Estadual do Alto Ribeira (PETAR), together with three other reserves: the Parque Estadual Intervales (PEI) - to the northeast, the Estação Ecológica Xitué and Parque Estadual Carlos Botelho - to the north and east, respectively, of the PEI, form a continuous ecological area of ca. 120,000 ha. (Galati et al. 2010).

The PETAR is situated in a transitional area between the Atlantic Plateau and the coastal plain on the left margin of the middle and upper course of the Ribeira river, in the southwest of São Paulo state $\left(24^{\circ} 12^{\prime}-24^{\circ} 25^{\prime} \mathrm{S}\right.$ and $48^{\circ}$ $03^{\prime}-48^{\circ} 30^{\prime} \mathrm{W}$ ), in Iporanga and Apiaí municipalities, on the Paranapiacaba range, at altitudes varying between 80 and 980 $\mathrm{m}$. It is drained by the basin of the Betari, Iporanga and Pilões rivers that have their watersheds on the edge of the Atlantic Plateau, locally denominated "Planalto de Guapiara". Its climate, according to Nimer (1977), represents a transition between a tropical low altitude zone and a temperate zone of intermediate altitude and is classified as sub-tropical and highly humid with no dry season. The average annual rainfall for 1970-1996 was 1,963.3 mm, of which $681.8 \mathrm{~mm}$ fell in the dry season (April - September) and $1,281.5 \mathrm{~mm}$ in the rainy season. The predominant vegetation is ombrophylous dense sub-mountain forest, with trees of up to 25-30 m and many lianas, ferns, epiphytes and palm trees (Karmann \& Ferrari 2002).

The PETAR has been divided into four logistic areas, denominated "nuclei": Santana, Caboclos, Ouro Grosso and Casa de Pedra, the majority of the tourist activities being concentrated in these areas. Some of these areas are exclusively used for recreation, others for environmental education and/or research (Carvalho et al. 2002). The PETAR received 43,324; 48,693 and 42,477 visitors, respectively, during 2001, 2002 and 2003, and the Santana nucleus accounted for $70-80 \%$ of them.

The area sampled belongs to the Santana nucleus (Fig. 1), situated on the right and left banks of the Betari River. On the right bank are the researchers' lodgings, the Santana cave and the camping site. A track beginning at the reception office leads to the main entrance of the Santana cave, about $800 \mathrm{~m}$ away. The researchers' lodgings are situated on this track, ca. $300 \mathrm{~m}$ from the main Santana cave mouth, the camping site, a grassy area $100 \mathrm{~m}$ long x $20 \mathrm{~m}$ wide, being situated some $120 \mathrm{~m}$ beyond the Santana cave entrance, on the right bank of the Betari River. This cave entrance is about $130 \mathrm{~m}$ from the right bank of the Betari. The Morro Preto and Couto caves, with an underground connection between them, are located on the left bank of the Betari River. A track which crosses the Betari gives access to the three caves. The distance between the principal entrances of the Santana and Couto caves is of about $180 \mathrm{~m}$, that between the former and the Morro Preto cave is of approximately $300 \mathrm{~m}$, and that between this latter and the Couto cave is of about $120 \mathrm{~m}$. These areas are in preserved primary forest with many bromeliaceas.

Caves studied: the Santana cave (24 $31^{\prime} 5100^{\prime \prime} \mathrm{S}, 48^{\circ}$ 42' 0600 " $\mathrm{W}, 250 \mathrm{~m}$ a.s.l.) presents a horizontal projection 
with $6.3 \mathrm{~km}$ of mapped passages, discontinuous linear development and a drop in level of $61 \mathrm{~m}$ (Karmann \& Ferrari 2002; Sociedade Brasileira de Espeleologia 2007). The main entrance is not very large $(4.0 \mathrm{~m}$ wide $\times 2.5 \mathrm{~m}$ high) and is fenced off. There is a skylight near this entrance. The cave's galleries and saloons are richly ornamented with stalactites, stalagmites and curtains. The Roncador River, a tributary of the Betari, runs through the cave and drains several of its galleries. Only $490 \mathrm{~m}$ is used as a tourist circuit (T. Gonçalves, pers. comm.). The Morro Preto cave (24 31' 1900" S, 48 41' 5400 " W, 305 m.a.s.l), has $832 \mathrm{~m}$ of horizontal projection, discontinuous linear development and a drop in level of 61 m (Sociedade Brasileira de Espeleologia 2007). It presents a great portico and giant stalactites. The Couto cave $\left(24^{\circ} 31^{\text {, }}\right.$ 1400 " S, $48^{\circ} 31^{\prime} 1400$ ", 290 m a.s.l), situated below the Morro Preto cave and linked to it, presents $471 \mathrm{~m}$ of horizontal projection, discontinuous linear development and a drop in level of $26 \mathrm{~m}$. A small river runs through it and when it leaves it does so as a waterfall. It has a small entrance $(\sim 2 \mathrm{~m}$ wide $\mathrm{x} 1.5$ high) about five metres from the waterfall on the track that gives access to the principal entrance of the Morro Preto cave.

Methodology. The captures were carried out monthly by two different techniques: i) automatic light traps (Natal et al. 1991) modified as follows: they have a no-break battery $(6 \mathrm{~V}$ and $12 \mathrm{~A})$ as energy source and an external collection chamber linked to the body of the trap by a sleeve, and ii) modified black and white Shannon traps (Galati et al. 2001).

A total of 11 ecotopes were sampled in the Santana nucleus with automatic light traps installed between $1.0 \mathrm{~m}$ and $2.0 \mathrm{~m}$ above ground level, from 18.00 to 07.00 hours, with the following distribution: a) on the right bank of the Betari River: 1) at the researchers' lodgings (veranda; 300 $\mathrm{m}$ a.s.1.); 2) on the rocks located $10 \mathrm{~m}$ from the principal entrance of the Santana cave, $262 \mathrm{~m}$ a.s.1. 3) at the principal Santana cave entrance; $260 \mathrm{~m}$ a.s.l. and 4) at the camp site, $260 \mathrm{~m}$ a.s.l.; b) on the left bank of the Betari river: 5) at the forest edge close to the river bank, $260 \mathrm{~m}$ a.s.l.; at three sites on the track that leads to the Morro Preto cave: 6) near a Ficus tree's roots among rocks, $280 \mathrm{~m}$ a.s.l., about $80 \mathrm{~m}$ from the river bank, 7) in a rocky wall at the beginning of the Morro Preto outcrop, $130 \mathrm{~m}$ from the river bank, $300 \mathrm{~m}$ a.s.l. and 8 ) at the end of the track, close to the principal Morro Preto cave entrance, $170 \mathrm{~m}$ from the river bank, $305 \mathrm{~m}$ a.s.l. 9) at the principal Couto cave entrance, situated about $50 \mathrm{~m}$ from the bank, $275 \mathrm{~m}$ a.s.l., 10), in the Morro Preto cave, $305 \mathrm{~m}$ a.s.l. (a shady zone, about $30 \mathrm{~m}$ from the main entrance) and 11) in the Morro Preto cave (dark zone about $110 \mathrm{~m}$ from the principal entrance).

The periods of capture at each site were different. The ecotopes 3, 5, 8, 10, and 11 were sampled from January 2001 to December 2002; 1, 4, 6, 9, from February 2001 to December 2002 and 2 from December 2001 to December 2002.

Diurnal captures were undertaken from $07.00-17.00$ hours both in the Morro Preto cave- (entrance - shady zone) and in its interior (dark zone), from January 2001 to December 2002.

The Shannon traps were installed monthly (except in
March 2001, due to the heavy rains) in forest close to the Betari River banks with modified white and/or black Shannon traps, from $18.00-22.00$ hours. Two members of the team captured the insects for the investigation of natural infection by flagellates, as described by Galati et al. (2003). The insects were captured in flasks which were kept in a polystyrene box lined with humid plaster of Paris until the females could be dissected.

The specimens captured with automatic light traps and the males captured with Shannon traps, after being killed with chloroform, were conditioned in Petri dishes and kept under refrigeration until their clarification by the method described by Forattini (1973) and their identification in accordance with Galati (2003b). A sample of these specimens is deposited in the collection of the Departamento de Epidemiologia of the Faculdade de Saúde Pública, USP.

The nomenclature of the phlebotomines follows Galati (2003a) and the abbreviation of the generic names of the species follows Marcondes (2007).

The pluviometric data of the PETAR were obtained from the Serra dos Motas meteorological station (240 m a.s.l.), Iporanga municipality (Sigrh 2007) and the temperature data of the Eldorado municipality, which borders on the PETAR, from the Centro Integrado de Informações Agrometeorológicas do Instituto Agronômico de Campinas (Ciiagro 2007).

Statistical analysis. The frequencies of the insects captured in simultaneous periods were obtained by Williams' geometric average (Haddow 1960). The $\chi^{2}$ test was used to assess the different frequencies of some species as between white and black Shannon traps.

The abundance and diversity of the species were obtained on the basis of the data of the captures carried out with automatic light traps. The Standardised Index of Species Abundance (SISA) was calculated in accordance with Roberts \& Hsi (1979) and Shannon's Diversity Index (H) and Pielou's Evenness Index (J) in accordance with Hayek and Buzas (1997).

Pearson's correlation coefficient was used in the search for possible correlations between the Williams' geometric average of the numbers of insects captured monthly in all the ecotopes and the rainfall of the previous 30 days before the monthly capture date, as also between the Williams' average and the average temperature for the month.

\section{RESULTS}

With the two techniques, automatic light and Shannon traps, used for the captures in the PETAR, a total of 2,449 specimens of phlebotomines, representing 21 species and four subtribes, were collected: Brumptomyiina - Brumptomyia cunhai (Mangabeira, 1942), Brumptomyia nitzulescui (Costa Lima, 1932), Brumptomyia troglodytes (Lutz, 1922) and Brumptomyia carvalheiroi Shimabukuro, Marassá \& Galati, 2007; Lutzomyiina - Evandromyia edwardsi (Mangabeira, 1941), Expapillata firmatoi (Barretto, Martins \& Pellegrino, 1956), Lutzomyia amarali (Barretto \& Coutinho, 1940), Lutzomyia longipalpis (Lutz \& Neiva, 1912), Migonemyia 
migonei (França, 1920), Pintomyia fischeri (Pinto, 1926), Pintomyia misionensis (Castro, 1959 ), Pintomyia monticola (Costa Lima, 1932) and Sciopemyia microps (Mangabeira, 1942); Psychodopygina - Nyssomyia intermedia (Lutz \& Neiva, 1912), Nyssomyia neivai (Pinto, 1926), Psathyromyia lanei (Barretto \& Coutinho, 1941), Psathyromyia pascalei (Coutinho \& Barretto, 1940), Psathyromyia sp., Psychodopygus ayrozai (Barretto \& Coutinho, 1940) and Psychodopygus geniculatus (Mangabeira, 1941) and Sergentomyiina - Micropygomyia petari Galati, Marassá \& Gonçalves-Andrade, 2003. Twenty species were captured with the automatic light traps (Table I) and 13 on the Shannon traps, Pi. misionensis being captured exclusively by this latter technique (Table VI).

In the captures with automatic light traps undertaken in 11 ecotopes and which yielded a total of 249 samples 2,300 specimens were obtained (Table I), Pa. pascalei being the most frequent (26.2\%) followed by $P a$. lanei (25.0\%), Ps. ayrozai (11.7\%), Pi. fischeri (8.2\%), Ps. geniculatus (7.7\%), $N y$. intermedia (4.2\%) and Ev. edwardsi (3.3\%). However, the abundance of the species does not correspond exactly to the order of frequency: Pa. pascalei and Ps. ayrozai were the only species captured in all the ecotopes, hence justifying their $1^{\text {st }}$ and $2^{\text {nd }}$ positions in the Standardized Index of Species Abundance (SISA), 0.922 and 0.848, respectively, in Table III.

Pa. lanei (SISA $=0.795)$, Ps. geniculatus (0.727) and Ev. edwardsi (0.558), which occupied the $3^{\text {rd }}, 4^{\text {th }}$ and $6^{\text {th }}$ positions, respectively, in abundance were absent from only one ecotope. The first two from the dark zone of the Morro Preto cave and the last from the entrance of the Couto cave. Pi. fischeri (SISA $=0.679 ; 5^{\text {th }}$ position $)$ and $N y$. intermedia $\left(\right.$ SISA $=0.489 ; 8^{\text {th }}$ position) were not captured in two ecotopes, the first in the two of the Morro Preto cave and the second in the dark zone of the Morro Preto cave and in the entrance of the Couto cave. Pi. monticola though present in low frequency $(1.8 \%)$, occupied the $7^{\text {th }}$ position in abundance (SISA $=0.533$ ) as it was not only captured in the dark zone of Morro Preto cave. At the other extreme was $\mathrm{Lu}$. longipalpis, the least frequent and least abundant species, only one specimen being captured in the dark zone of the Morro Preto cave.

The greatest species richness (18) was obtained near the Ficus tree's roots and the rock wall of the Morro Preto outcrop, and the lowest (8) in the dark zone of the Morro Preto cave.

The highest values of Shannon's diversity $(\mathrm{H})$ and evenness ( $\mathrm{J}$ ) indices occurred in the domicile, on the rocks near the entrance of the Santana cave and in the entrance of this same cave, H being 2.20, 2.056, 2.053 and $\mathrm{J} 0.858,0.779$, 0.856 , respectively; the lowest values occurring in the two ecotopes of the Morro Preto cave: the dark zone $(\mathrm{H}=1.145$; $\mathrm{J}$ $=0.551)$ and the entrance $(\mathrm{H}=1.342 ; \mathrm{J}=0.540)$.

The greatest species predominance by ecotope occurred with Ev. edwardsi in the dark zone of the Morro Preto cave (70.6\%). Pa. pascalei predominated over the other species in the Morro Preto cave entrance (62.1\%), at the top of the track $(31.3 \%)$, in the rocky wall at the beginning of the Morro

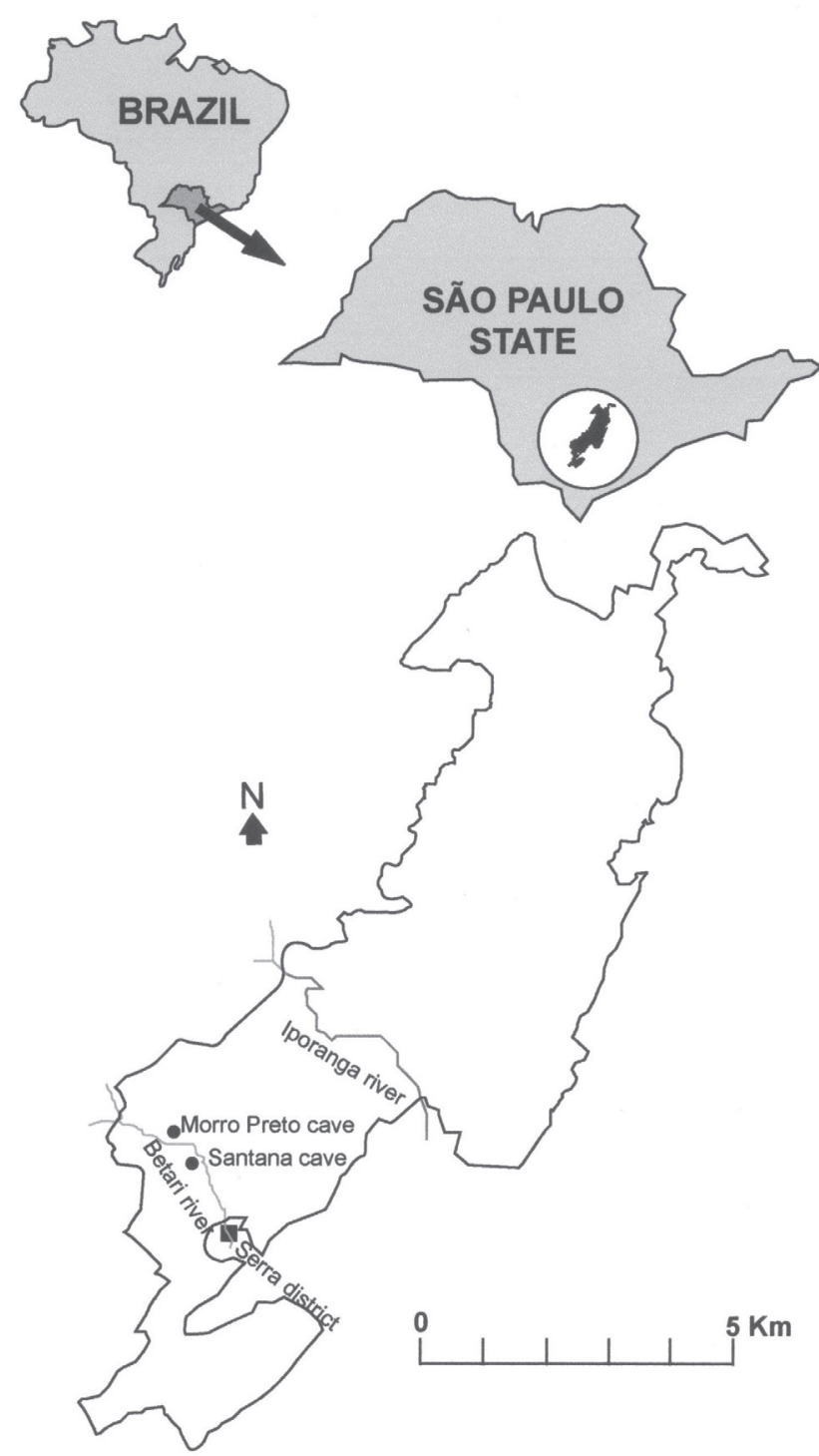

Fig. 1. Localization of the Santana and Morro Preto caves in the PETAR. Source: adapted from Karmann \& Ferrari 2002.

Preto outcrop (32.8\%) and on the veranda of the domicile (30.9\%); Pa. lanei, among the rocks near the Santana cave entrance (38.9\%), in the Santana cave mouth itself (38.5\%), in the Couto cave entrance $(37.2 \%)$ and near the Ficus tree's roots $(28.2 \%)$. Pi. fischeri, on the edge of the forest on the left bank of the Betari River (34.8\%) and Ny. intermedia on the camping site $(49.3 \%)$.

The average of sandflies captured per trap in all the ecotopes during the common intervals (December 2001 to December 2002), obtained by the arithmetical and Williams' geometric means (Table I), presented the highest values among the rocks close to the Santana cave mouth (26.08 and 8.59 insects/capture, respectively). The second greatest arithmetical mean (21.00 insects/capture) was found in the traps installed near the Ficus tree's roots, but Williams' geometric mean was smaller (4.86) than those of the rock walls of the Morro Preto outcrop (8.26), the camping site 

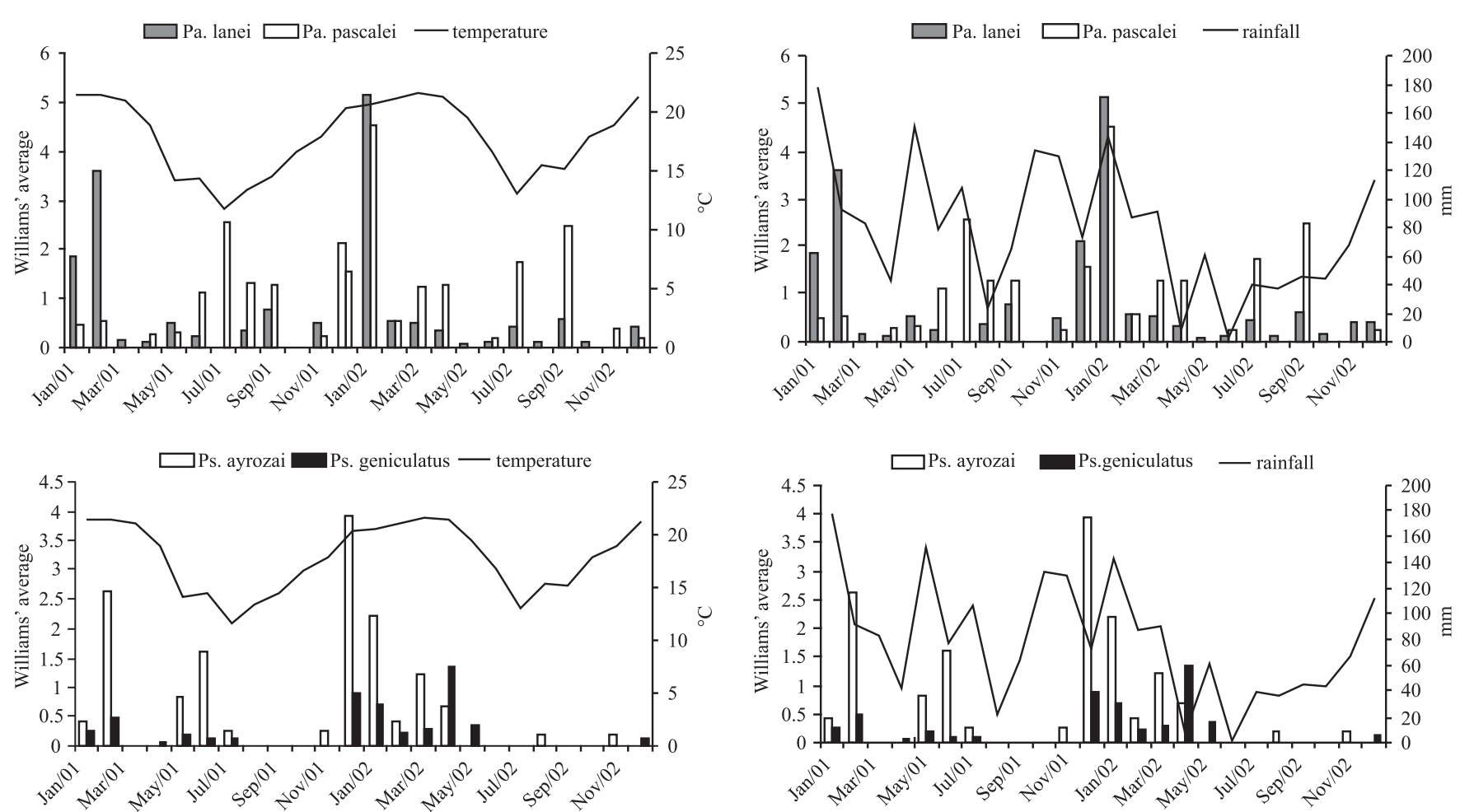

Fig. 2. Monthly distribution of the four most frequent sand fly species: Pa. lanei, Pa. pascalei, Ps. ayrozai and Ps. geniculatus in the PETAR from January 2001 to December 2002, rainfall and minimum average temperature of the 30 days before the day of capture.

(5.77) and at the top of the track to the Morro Preto cave (5.32). The smallest values were observed in the Santana cave mouth (arithmetical and geometric means being 1.0 and 0.79 insects/capture, respectively) and in the dark zone of the Morro Preto cave (1.85 and 1.21). In the majority of the ecotopes the values of the arithmetical averages of the period before the common one were close to each other, but were highest in the common period on the camping site and in the entrance of the Morro Preto cave.

In the collections undertaken in the diurnal period in the Morro Preto cave (mouth and interior) only two females of Pa. pascalei were captured, and this in January 2002.

The distribution by sex in the total of specimens captured shows more females than males (female/male ratio $=1.52: 1.0$ ). Only females of $\mathrm{Lu}$. amarali, Lu. longipalpis, Psathyromyia sp., Sc. microps and Pi. monticola were captured, this latter species being one the most abundant. Males and females of $N y$. neivai were captured in approximately equal numbers. Males predominated among the species of Brumptomyia, excepting Br. carvalheiroi, and among those of Pa. pascalei (the male/female ratio varying from 1.5:1.0 to 2.1:1.0), and in the 11 remaining species the females predominated (the female/male ratio varying from $1.15: 1.0$ to $11.0: 1.0$ ).

The monthly distribution is only presented for the most abundant species: Pa. lanei, Pa. pascalei, Ps. ayrozai and Ps. geniculatus, in Fig. 2. When Pearson's Correlation coefficients were calculated as between the Williams' geometrical average of both sexes captured monthly with automatic light traps in all the ecotopes of PETAR in relation to the monthly rains during the 30 days before the capture day and the monthly minimum average temperature $(n=24)$, a positive statistically significant correlation was obtained in relation to the rains for $P a$. lanei $(\mathrm{r}=0.50, \mathrm{p}=0.012)$ and Ps. ayrozai $(\mathrm{r}=0.57, \mathrm{p}=0.004)$, but low positive correlation and no statistical significance for Pa. pascalei $(\mathrm{r}=0.09, \mathrm{p}=$ $0.678)$ and Ps. geniculatus $(\mathrm{r}=0.16, \mathrm{p}=0.462)$. As regards temperature, a low negative correlation was found for $P a$. pascalei $(\mathrm{r}=-0.176, \mathrm{p}=0.411)$ and a positive one for $\mathrm{Pa}$. lanei $(\mathrm{r}=0.378, \mathrm{p}=0.069)$, Ps ayrozai $(\mathrm{r}=0.324, \mathrm{p}=0.122)$ and Ps. geniculatus $(\mathrm{r}=0.502, \mathrm{p}=0.012)$, only this latter, however, being of statistical significance.

In 21 collections undertaken simultaneously with black and white Shannon traps a total of 107 specimens belonging to 13 species were captured, twelve of them on the black and six on the white trap (Table IV). A greater number of specimens was captured on the black traps (67) than on the white (40), the difference being statistically significant $\left(\chi^{2}=6.81 ; p<0.01\right)$. Traps of both colors captured more females than males, but the difference between the number of specimens of each sex collected was greater on the white (white female/male ratio $=12.33: 1.0 ; \chi^{2}=28.9 ; \mathrm{p}<0.001$ ) than on the black (female /male ratio $=2.53: 1.0 ; \chi^{2}=12.55$; $\mathrm{p}<0.001$. On the black trap, both sexes of Ps. geniculatus predominated (male, $42.1 \%$ and females, $43.75 \%$ ) in relation to those of the other species, but only the females presented a statistically significant difference over those of the other species, Ps. geniculatus being captured 2.63 times more than those of Pi. fischeri, the second most frequent $\left(\chi^{2}=5.83\right.$; $<<$ $0.02)$. On the white traps, females of two species, $P a$. lanei and Ps. ayrozai, predominated equally (32.4\%); the difference 
Table I. Number of both sexes of phlebotomines captured in the PETAR with automatic light traps by species and ecotope, between January 2001 and December 2002, and the averages of the total and simultaneous periods of capture, the Williams' geometric mean of the simultaneous period of capture, the Shannon diversity $(\mathrm{H})$ and the Pielou evenness $(\mathrm{J})$ indices by ecotope.

\begin{tabular}{|c|c|c|c|c|c|c|c|c|c|c|c|c|c|}
\hline Ecotope & $\begin{array}{c}\text { Santana } \\
\text { cave } \\
\text { entrance }\end{array}$ & $\begin{array}{l}\text { Rocks } \\
\text { close to } \\
\text { Santana } \\
\text { entrance }\end{array}$ & $\begin{array}{l}\text { Camp } \\
\text { site }\end{array}$ & $\begin{array}{c}\text { Forest } \\
\text { edge }\end{array}$ & $\begin{array}{l}\text { Ficus } \\
\text { tree } \\
\text { roots/ } \\
\text { rocks }\end{array}$ & $\begin{array}{c}\text { Rocky } \\
\text { wall - } \\
\text { M. Preto } \\
\text { outcrop }\end{array}$ & $\begin{array}{c}\text { Couto } \\
\text { cave } \\
\text { entrance }\end{array}$ & $\begin{array}{c}\text { Top of } \\
\text { the } \\
\text { track }\end{array}$ & $\begin{array}{c}\text { Morro } \\
\text { Preto } \\
\text { cave } \\
\text { entrance }\end{array}$ & $\begin{array}{c}\text { M. Preto } \\
\text { cave } \\
\text { dark } \\
\text { zone }\end{array}$ & $\begin{array}{c}\text { Domicile } \\
\text { veranda }\end{array}$ & Total & $\%$ \\
\hline N. captures & 24 & 13 & 23 & 24 & 23 & 24 & 23 & 24 & 24 & 24 & 23 & 249 & \\
\hline Br. carvalheiroi & - & 1 & - & 2 & 2 & 3 & - & 3 & 1 & - & - & 12 & 0.522 \\
\hline Br. cunhai & - & 22 & 12 & - & 12 & 18 & 1 & 2 & - & 1 & 1 & 69 & 3.000 \\
\hline Br. nitzulescui & - & 10 & 1 & - & 5 & 6 & 3 & 8 & - & 1 & 4 & 38 & 1.653 \\
\hline Br. troglodytes & - & 2 & - & - & 2 & 1 & 2 & 3 & - & - & 5 & 15 & 0.652 \\
\hline Ev. edwardsi & 2 & 12 & 1 & 1 & 5 & 10 & - & 2 & 18 & 24 & 2 & 77 & 3.348 \\
\hline Ex. firmatoi & - & - & - & - & 3 & 2 & - & 4 & 2 & 1 & - & 12 & 0.522 \\
\hline Lu. amarali & 1 & - & - & - & 3 & 1 & - & - & 1 & - & - & 6 & 0.261 \\
\hline Lu. longipalpis & - & - & - & - & - & - & - & - & - & 1 & - & 1 & 0.044 \\
\hline Mi. petari & 1 & 10 & - & - & 1 & 24 & - & 5 & 2 & 1 & - & 44 & 1.913 \\
\hline Mg. migonei & - & 6 & - & 1 & 17 & 1 & - & 8 & - & - & 5 & 38 & 1.652 \\
\hline Ny. intermedia & 2 & 12 & 67 & 2 & 3 & 2 & - & 3 & 3 & - & 3 & 97 & 4.217 \\
\hline Ny. neivai & 1 & - & 10 & 9 & 2 & 1 & - & 1 & - & - & - & 24 & 1.044 \\
\hline Pa. lanei & 10 & 132 & 1 & 19 & 137 & 144 & 32 & 92 & 2 & - & 6 & 575 & 25.000 \\
\hline Pa.pascalei & 2 & 35 & 9 & 12 & 105 & 161 & 27 & 110 & 113 & 3 & 25 & 602 & 26.174 \\
\hline$P a$. sp. & - & - & - & - & 3 & 1 & - & 4 & 3 & - & - & 11 & 0.478 \\
\hline Pi. fischeri & 1 & 24 & 18 & 31 & 42 & 20 & 11 & 31 & - & - & 11 & 189 & 8.217 \\
\hline Pi. monticola & 2 & 9 & 3 & 3 & 6 & 9 & 1 & 6 & 2 & - & 1 & 42 & 1.826 \\
\hline Ps. ayrozai & 2 & 45 & 4 & 6 & 61 & 58 & 4 & 51 & 26 & 2 & 9 & 268 & 11.652 \\
\hline Ps. geniculatus & 2 & 19 & 10 & 3 & 76 & 29 & 4 & 18 & 9 & - & 8 & 178 & 7.739 \\
\hline Sc.microps & - & - & - & - & - & - & 1 & - & - & - & 1 & 2 & 0.087 \\
\hline Total & 26 & 339 & 136 & 89 & 485 & 491 & 86 & 351 & 182 & 34 & 81 & 2300 & 100.000 \\
\hline Average (total period) & 1.08 & 26.08 & 5.91 & 3.71 & 21.09 & 20.46 & 3.74 & 14.63 & 7.58 & 1.42 & 3.52 & 9.24 & \\
\hline Average (simult. period) & 1.00 & 26.08 & 9.23 & 3.31 & 21.00 & 19.69 & 5.08 & 14.00 & 11.69 & 1.85 & 3.08 & 9.62 & \\
\hline $\begin{array}{l}\text { Williams' geom. mean } \\
\text { (simultaneous period) }\end{array}$ & 0.79 & 8.59 & 5.77 & 2.05 & 4.86 & 8.26 & 1.91 & 5.32 & 3.49 & 1.21 & 1.50 & 3.16 & \\
\hline $\mathrm{H}$ & 2.053 & 2.056 & 2.015 & 1.881 & 2.016 & 1.970 & 1.503 & 1.964 & 1.342 & 1.145 & 2.200 & 2.174 & \\
\hline $\mathrm{J}$ & 0.856 & 0.779 & 0.841 & 0.784 & 0.697 & 0.682 & 0.653 & 0.693 & 0.540 & 0.551 & 0.858 & 0.779 & \\
\hline
\end{tabular}

between the frequency of these species and that of the second most frequent, Pi. fischeri (16.2\%) being without significance $\left(\chi^{2}=2.0 ; \mathrm{p}>0.05\right)$, but statistically significant in relation to that of the third most frequent Ps. ayrozai $(10.8 \%) ;\left(\chi^{2}=4.0\right.$; $\mathrm{p}<0.05)$.

Beyond these captures, two others (in January and February 2001) were undertaken with black traps only; during the former month heavy rain fell and no insect was captured, in the latter month a total of 42 specimens of two species, $P s$. ayrozai ( 2 males and 26 females) and Ps. geniculatus ( 1 male and 13 females) were collected. Thus with this color a total of 149 sand flies were captured and the numbers of females of Ps. geniculatus (34) and Ps. ayrozai (32) presented no statistically significant difference $\left(\chi^{2}=0.25 ; \mathrm{p}>0.90\right)$, the two species being practically equally attracted to the black Shannon traps.

Another 36 specimens (Pa. lanei $1 \mathrm{~F}$, Ps. ayrozai $25 \mathrm{~F}$ and Ps. geniculatus $1 \mathrm{M}, 9 \mathrm{~F}$ ) were captured landing on the researchers while these were positioned in the Shannon traps. Thus Ps. ayrozai was 2.8 times more attracted to humans than was Ps. geniculatus $\left(\chi^{2}=7.53 ; \mathrm{p}<0.01\right)$.

A total of 66 females belonging to the following species: Br. cunhai (5), Br. nitzulescui (4), Br. carvalheiroi (1), Ev. edwardsi (7), Mi. petari (1), Mg. migonei (1), Ny. neivai (1), Pi. fischeri (8), Pi. monticola (3), Pa. lanei (13), Pa. pascalei (7), Psathyromyia sp. (1), Ps. ayrozai (10) and Ps. geniculatus (4) were captured with automatic light or Shannon traps and dissected for investigation of flagellates in their digestive tracts, with negative results.

\section{DISCUSSION}

Among the sand fly fauna captured in the PETAR, apart from $\mathrm{Br}$. cunhai, Lu. longipalpis and Pi. misionensis - not previously registered in the Ribeira Valley, all the other species had been reported in one or other of the series of ecological studies undertaken in this region of the São Paulo state (Forattini et al. 1976; Gomes et al. 1978, 1980, 1982, 1983, 1986, 1990; Gomes \& Galati 1987, 1989; Domingos et al. 1998; Taniguchi et al. 2002; Andrade-Filho et al. 2007; Galati et al. 2003). Although neither of the two last species had been found in the Atlantic forest on the north coast of São Paulo state, Br. cunhai had (Brito et al. 2002).

On the other hand, some species found in other areas of the Ribeira Valley, such as Brumptomyia bragai Mangabeira \& Sherlock, 1961, Bichomomyia flaviscutellata 
Table II. Number of phlebotomines captured in the PETAR with automatic light traps by species, sex and ecotope, between January 2001 and December 2002.

\begin{tabular}{|c|c|c|c|c|c|c|c|c|c|c|c|c|c|c|c|c|c|c|c|c|c|c|c|c|}
\hline \multirow[t]{2}{*}{ Species } & \multicolumn{2}{|c|}{$\begin{array}{c}\text { Santana } \\
\text { cave } \\
\text { entrance }\end{array}$} & \multicolumn{2}{|c|}{$\begin{array}{c}\text { Rocks } \\
\text { close to } \\
\text { Santana } \\
\text { entrance }\end{array}$} & \multicolumn{2}{|c|}{$\begin{array}{c}\text { Camp } \\
\text { site }\end{array}$} & \multicolumn{2}{|c|}{$\begin{array}{c}\text { Forest } \\
\text { edge }\end{array}$} & \multicolumn{2}{|c|}{$\begin{array}{l}\text { Ficus } \\
\text { tree } \\
\text { roots/ } \\
\text { rocks }\end{array}$} & \multicolumn{2}{|c|}{$\begin{array}{c}\text { Rocky } \\
\text { wall of the } \\
\text { M. Preto } \\
\text { outcrop }\end{array}$} & \multicolumn{2}{|c|}{$\begin{array}{c}\text { Couto } \\
\text { cave } \\
\text { entrance }\end{array}$} & \multicolumn{2}{|c|}{$\begin{array}{c}\text { Top of } \\
\text { the track }\end{array}$} & \multicolumn{2}{|c|}{$\begin{array}{c}\text { Morro } \\
\text { Preto } \\
\text { cave } \\
\text { entrance }\end{array}$} & \multicolumn{2}{|c|}{$\begin{array}{l}\text { M. Preto } \\
\text { cave } \\
\text { dark } \\
\text { zone }\end{array}$} & \multicolumn{2}{|c|}{$\begin{array}{l}\text { Domicile } \\
\text { veranda }\end{array}$} & \multicolumn{2}{|c|}{ Total } \\
\hline & $\mathrm{M}$ & $\mathrm{F}$ & $\mathrm{M}$ & $\mathrm{F}$ & M & $\mathrm{F}$ & $\mathrm{M}$ & $\mathrm{F}$ & $\mathrm{M}$ & $\mathrm{F}$ & M & $\mathrm{F}$ & $\mathrm{M}$ & $\mathrm{F}$ & $\mathrm{M}$ & $\mathrm{F}$ & M. & $\mathrm{F}$ & $\mathrm{M}$ & $\mathrm{F}$ & $\mathrm{M}$ & $\mathrm{F}$ & $\mathrm{M}$ & $\mathrm{F}$ \\
\hline Br. carvalheiroi & - & - & - & 1 & - & - & - & 2 & - & 2 & - & 3 & - & - & 1 & 2 & - & 1 & - & - & - & - & 1 & 11 \\
\hline Br. cunhai & - & - & 21 & 1 & 8 & 4 & - & - & 8 & 4 & 7 & 11 & - & 1 & 1 & 1 & - & - & 1 & . & 1 & - & 47 & 22 \\
\hline Br. nitzulescui & - & - & 6 & 4 & 1 & - & - & - & 1 & 4 & 4 & 2 & 2 & 1 & 5 & 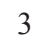 & - & - & 1 & & 4 & - & 24 & 14 \\
\hline glodvtes & - & - & 2 & - & - & - & - & - & 2 & - & 1 & - & 1 & 1 & 1 & 2 & - & - & - & - & 2 & 3 & 9 & 6 \\
\hline Ev. edwardsi & - & 2 & 1 & 11 & - & 1 & 1 & - & - & 5 & 2 & 8 & - & - & - & 2 & 5 & 13 & 7 & 17 & 1 & 1 & 17 & 60 \\
\hline x. firmatoi & - & - & - & - & - & - & - & - & - & 3 & - & 2 & - & - & 1 & 3 & - & 2 & - & 1 & - & - & 1 & 11 \\
\hline Lu. a & - & 1 & - & - & - & - & - & - & - & 3 & - & 1 & - & - & - & - & - & 1 & - & - & - & - & - & 6 \\
\hline ngipal & - & - & - & - & - & - & - & - & - & - & - & 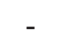 & - & - & - & - & - & - & - & 1 & - & - & - & 1 \\
\hline ari & - & 1 & - & 10 & - & - & - & - & - & 1 & 3 & 21 & - & - & 2 & 3 & 1 & 1 & - & 1 & - & - & 6 & 38 \\
\hline 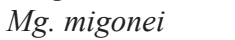 & - & - & 1 & 5 & - & - & - & 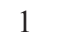 & 3 & 14 & - & 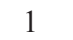 & - & - & - & 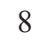 & - & - & - & - & 1 & 4 & $J$ & 33 \\
\hline$y$. & 1 & 1 & 9 & 3 & 24 & 4 & - & 2 & 2 & 1 & 1 & 1 & . & - & 3 & & 2 & 1 & - & 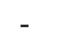 & 3 & - & 5 & 2 \\
\hline & 1 & - & - & & 4 & 6 & 4 & 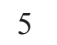 & 2 & - & 1 & - & - & - & - & 1 & - & - & - & - & - & - & 12 & 12 \\
\hline a. lanei & 2 & 8 & 52 & 80 & - & 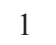 & 2 & 17 & 37 & 100 & 42 & 102 & 4 & 28 & 22 & 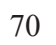 & - & 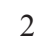 & - & - & 2 & 4 & 163 & 412 \\
\hline Pa.p & 2 & - & 32 & 3 & 4 & 5 & 7 & 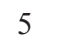 & 79 & 26 & 105 & 56 & 19 & 8 & 73 & 37 & 58 & 55 & 3 & - & 16 & 9 & 398 & 204 \\
\hline$P a$. sp. & - & - & - & - & - & - & - & - & - & 3 & - & 1 & - & - & - & 4 & - & 3 & - & - & - & - & - & 11 \\
\hline Pi. fischeri & - & 1 & - & 24 & 3 & 15 & 2 & 29 & 9 & 33 & - & 20 & 2 & 9 & 4 & 27 & - & - & - & - & 1 & 10 & 21 & 168 \\
\hline Pi. $m$ & - & 2 & - & 9 & - & 3 & - & 3 & - & 6 & - & 9 & - & 1 & - & 6 & - & 2 & - & - & - & 1 & - & 42 \\
\hline Ps. a & 1 & 1 & 11 & 34 & - & 4 & 1 & 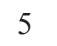 & 19 & 42 & 26 & 32 & 2 & 2 & 13 & 38 & 12 & 14 & 1 & 1 & 7 & 2 & 93 & 175 \\
\hline niculatus & 1 & 1 & 12 & 7 & 7 & 3 & 1 & 2 & 30 & 46 & 9 & 20 & 1 & 3 & 5 & 13 & 2 & 7 & - & - & 1 & 7 & 69 & 109 \\
\hline Sc. microps & - & - & - & - & - & - & - & - & - & - & - & - & - & 1 & - & - & - & - & - & - & - & 1 & - & 2 \\
\hline Total & 8 & 18 & 147 & 192 & 51 & 85 & 18 & 71 & 192 & 293 & 201 & 290 & 31 & 55 & 131 & 220 & 80 & 102 & 13 & 21 & 39 & 42 & 911 & 1389 \\
\hline
\end{tabular}

(Manganeira, 1942), Micropygomyia ferreirana (Barretto, Martins \& Pellegrino, 1956 (= Mi. borgmeieri; Galati et al. 2003); Evandromyia petropolitana (Martins \& Silva, 1968), Migonemyia rabelloi (Galati \& Gomes, 1992) and Migonemyia vaniae Galati, Fonseca \& Marassá, 2007, this latter described from the Serra district, Iporanga municipality (Galati et al. 2007), were not captured in the PETAR.

Two other species had been reported for the Ribeira Valley region: Pa. shannoni (Dyar, 1929) and Ps. guyanensis (Floch $\&$ Abonnenc, 1941). The former was wrongly identified, being in fact $P a$. pestanai. The second was considered as senior synonym of $P$ s. geniculata by Forattini (1973), but in accordance with Young \& Duncan (1994), Ps. guyanensis is a valid species and has its distribution restricted to French Guyana (Domingos et al. 1998).

Comparing the phlebotomine fauna and its behavior in PETAR with those of the Parque Estadual Intervales (PEI), both parks belonging to the same ecological continuum, but whose sites were sampled at different altitudes, 260-305 m and 780-950 m, respectively, several differences and some similarities were observed: i) though in both of the areas a total of 21 species were captured, only 17 were common to both: Br. cunhai, Br. troglodytes, Br. carvalheiroi, Ev. edwardsi, Ex. firmatoi, $\mathrm{Mg}$. migonei, Mi. petari, $\mathrm{Ny}$. intermedia, $\mathrm{Ny}$. neivai, Pi. fischeri, Pi. monticola, Pa. lanei, Pa. pascalei, Psathyromyia sp., Ps. ayrozai, Ps. geniculatus and Sc. microps. Four species were captured exclusively in the PETAR: $B r$. nitzulescui, Lu. amarali, Lu. longipalpis and Pi. misionensis and four others in the PEI: Br. bragai, Ev. correalimai, $M g$. rabelloi and Sc. sordellii; ii) the mean number of insects per trap during the same period of capture (with automatic light traps) in the PETAR was 9.24, while in the PEI it was 1.92 $\left(\chi^{2}=4.8 ; p<0.05\right)$, these difference being most evident in the extradomiciliary areas, since on the veranda of the respective domicile sampled in the PETAR and the PEI this number is quite similar (3.19 and 3.52, respectively); iii) although the species richness is not greatly different, 20 species in PETAR and 18 in PEI, the most abundant species in the PETAR is $P a$. pascalei and that in the PEI, Br. troglodytes. The $2^{\text {nd }}$ and $4^{\text {th }}$ most abundant in the PETAR, Ps. ayrozai and Ps. geniculatus respectively, are among those of low abundance in the PEI. Coincidentally, $\mathrm{Pa}$. lanei had the second greatest frequency in both parks; iv) in the dark zone of the Morro Preto cave (PETAR) twice as many insects were captured as in the Colorida cave (PEI), 34 and 17, respectively; in the mouth of Morro Preto 13 times more insects were captured than in the Minotauro cave (PEI), 182 and 14, respectively; v) in the captures with Shannon traps and on the researchers females of Ps. ayrozai and Ps. geniculatus predominated in PETAR, while in the PEI the predominance was Pi. monticola's. A series of other differences may be cited, but noteworthy in the PETAR was the capture of Lutzomyia longipalpis, the main vector of visceral leishmaniasis in the Americas, and of $N y$. intermedia, and $N y$. neivai, important vectors of cutaneous leishmaniasis in the Brazilian Southeast region, and the most frequent on the open camping site.

Lu. longipalpis, although widely distributed from Mexico to Argentina, mainly in savannah/cerrado, caatinga and semiarid vegetation, and despite its being common in coastal areas of the Brazilian Northeast region and some others of 
the Southeast, such as the state of Rio de Janeiro, had not been found in the moist Atlantic forest of the Serra do Mar/ Paranapiacaba in São Paulo state, before this project. The finding of a female in the dark zone of the Morro Preto cave and one male in the Shannon trap installed close to the Santana cave suggests its association with this ecotope. Thus it is possible that during the cold, dry Würm-Wisconsin glacial period of the Pleistocene $(13,000$ and 20,000 years B.P.), populations of this species had dispersed throughout the area covered by semi-arid vegetation on the southeastern coast of Brazil, one of the three broad routes of expansion provided by this open vegetation formation (Brown \& Ab' Saber, 1979). When this period finished and there was dispersion of dense and humid vegetation throughout the speleological province of the Ribeira Valley, populations of this sand fly were preserved in caves. Thus, probably the gene flux among other South American populations has been interrupted since then. As Lu. longipalpis, has, throughout the Americas, been considered a cryptic species-complex, consisting of at least four clades, the majority of Brazilian populations constituting one of them (Arrivillaga et al. 2003), the analysis of specimens of this speleological province will perhaps help us better to understand the relationship among the various South American populations.

The sympatric occurrence of $N y$. intermedia and $N y$. neivai in the Ribeira Valley had already been reported (Marcondes et al. 1998) after the latter species, previously considered a junior synonym of the former, had been validated by Marcondes (1996). The predominance of these two species at the camping site (a narrow open grassy strip) was not a surprise, since $N y$. intermedia s. lat, had been at least 8 times more frequently captured on the edge of forest than within it in Pariquera Açu (Gomes \& Galati 1987), and 3.9 times more frequently in the same circumstances in Pedro de Toledo (Domingos et al. 1998), both municipalities in the Ribeira Valley region. In the southwestern region of São Paulo state this same value was 5.1 times (Condino et al. 1998). In this latter area this taxon has been identified as Ny. neivai (Marcondes et al. 1998). Thus the presence of these two species at the camping site of Petar where people spend the night may expose the latter to the risk of infection by Leishmania since these sandflies are anthropophilic, as demonstrated for $N y$. neivai by Gomes et al. (1989) and Pinto et al. (2001) and for Ny. intermedia by Aguiar et al. (1996) and Souza et al. (2001, 2005); they have also been found to be naturally infected by trypanosomatids: Ny. neivai by Forattini \& Santos (1952), Forattini et al. (1972), Casanova et al. (1995) and Córdoba-Lanus et al. (2006) and Ny. intermedia by Aragão (1922), Rangel et al. (1984) and Pita-Pereira et al. (2005), and each species occurs with the highest frequencies in allopatric areas in the state of São Paulo (Marcondes et al. 1998) where the transmission of ACL occurs (Camargo-Neves et al. 2002).

The greatest frequencies of $P a$. pascalei at the sites situated on the track to Morro Preto cave, including the Morro Preto cave mouth, and the domicile, all these in hilly areas, suggest a higher concentration of armadillo borrows in this terrain, since this sand fly is clearly associated with these ecotopes (Galati et al. 2010). Similar results were
Table III. Standardized Index Species Abundance obtained in the captures with automatic light traps in eleven ecotopes of the PETAR, between January 2001 to December 2002.

\begin{tabular}{lccc}
\hline Species & ISA & SISA & Position \\
\hline Br. cunhai & 11.04545 & 0.442 & $9^{\text {th }}$ \\
Br. nitzulescui & 11.13636 & 0.437 & $10^{\text {th }}$ \\
Br. carvalheiroi & 15.36364 & 0.202 & $16^{\text {th }}$ \\
Br. troglodytes & 15.13636 & 0.215 & $15^{\text {th }}$ \\
Ev. edwardsi & 8.954545 & 0.558 & $6^{\text {th }}$ \\
Ex. firmatoi & 14.90909 & 0.227 & $14^{\text {th }}$ \\
Lu. amarali & 16.59091 & 0.134 & $18^{\text {th }}$ \\
Lu. longipalpis & 17.81818 & 0.066 & $20^{\text {th }}$ \\
Mi. petari & 12.86364 & 0.341 & $11^{\text {th }}$ \\
Mg. migonei & 13.86364 & 0.285 & $12^{\text {th }}$ \\
Ny. intermedia & 10.19091 & 0.489 & $8^{\text {th }}$ \\
Ny. neivai & 14.72727 & 0.237 & $13^{\text {th }}$ \\
Pa. lanei & 4.681818 & 0.795 & $3^{\text {rd }}$ \\
Pa. pascalei & 2.409091 & 0.922 & $1^{\text {st }}$ \\
Pa. sp. & 16.13636 & 0.159 & $17^{\text {th }}$ \\
Pi. fischeri & 6.772727 & 0.679 & $5^{\text {th }}$ \\
Pi. monticola & 9.409091 & 0.533 & $7^{\text {th }}$ \\
Ps. ayrozai & 3.727273 & 0.848 & $2^{\text {nd }}$ \\
Ps. geniculatus & 5.909091 & 0.727 & $4^{\text {th }}$ \\
Sc. microps & 17.45455 & 0.086 & $19^{\text {th }}$ \\
\hline
\end{tabular}

observed by Aguiar et al. (1985) who captured Psathyromyia barrettoi (Mangabeira, 1942), also in light traps, a species that presents a close affinity with $P$ a. pascalei, presenting its highest frequency $(46.0 \%)$ on the Serra dos Órgãos (380 m a.s.1.), state of Rio de Janeiro. On the other hand, Marcondes et al. (2001) captured Pa. pascalei with CDC traps in low frequencies $(1.68 \%$ in canopy and $1.85 \%$ on the ground) in an Atlantic forest fragment in the low-lying eastern part of the Paraná state (10 $\mathrm{m}$ a.s.l).

The soil among the rocks close to the principal Santana cave mouth, among ficus tree roots and on the Morro Preto hill, seems to offer adequate breeding or resting sites for the anthropophilic species $\mathrm{Mg}$. migonei, Pi. fischeri, Pi. monticola, Pa. lanei, Ps. ayrozai and Ps. geniculatus and also for $M i$. petari which probably bites cold-blooded animals.

Of the two specimens of $L u$. longipalpis captured in PETAR, one was caught in the dark zone of the Morro Preto cave and the other on a Shannon trap in front of the Santana cave mouth. Ev. edwardsi, having a frequency of $70.5 \%$ in the dark zone of the Morro Preto cave, also seems to be a species adapted to living in caves. But as this latter species was also captured in the external environment, they may both be considered troglophiles.

As the Morro Preto cave has a large entrance, many species may use the area as a resting site or be attracted by the light of the trap. As regards the predominance of $\mathrm{Pa}$. pascalei $(61.0 \%)$, the possibility of armadillo borrows in the soil in its interior, or very close to it, cannot be ignored since both sexes were captured in practically equal numbers; while at the other sites generally the males predominated.

As regards the association with the rains during the 30 days before the capture, all the four most abundant species showed positive correlations, but only $P a$. lanei and $P S$. ayrozai presented statistical significance $(\mathrm{p}<0.05)$. In 
relation to the temperatures of the months, as distinct from the other three species which presented positive correlation, that for $P$ a. pascalei was negative, although without statistical significance. This probably occurred due to the increase of its population in the armadillo borrows during the driest and coldest period, as observed in the PEI (Galati et al. 2010). The highest frequencies observed in the Serra dos Órgãos, Rio de Janeiro state, from June to August, mainly in July, by Aguiar et al. (1985) for Pa. barrettoi, a species also belonging to the same subgenus (Forattiniella) of Pa. pascalei, seems to confirm that the coldest period is the most favorable for the capture of adults of this group of insects.

The Shannon traps tend to capture more anthropophilic species. Among the 13 species captured on these traps, only Ev. edwardsi and Mi. petari are known as non-anthropophilic. Thus the higher frequencies of Ps. ayrozai and Ps. geniculatus suggest that they are the most bothersome species to humans in the PETAR, confirmed by their capture while biting humans. Ps. ayrozai, also found in the Atlantic forest of the Ribeira Valley, São Paulo state (Gomes \& Galati 1989) and on the Serra dos Órgãos, Rio de Janeiro state (Aguiar et al. 1985) has presented a high degree of anthropophily, $69.3 \%$ and $57.5 \%$, respectively, of the specimens being attracted by human bait at ground level; but though less anthropophilic in Amazonia, it is suspected of transmitting Leishmania naiffi, for which armadillos are the reservoir, to humans (Rangel \& Lainson 2003). In forests of the Bahia states it was found to be predominant species (31.15\%) (Vexenat et al. 1986) and was highly susceptible to experimental infection by Leishmania (L.) forattinii Yoshida et al. 1993 from a wild rodent (Barretto et al. 1986; Lainson \& Shaw, 2005). The positive correlation of Ps. ayrozai with the most humid period was also observed by Aguiar et al. (1985) and Marcondes et al. (2001).

Whereas in several other Atlantic and Amazonian areas Ps. geniculatus has been frequently captured, although with relatively low frequencies, in the Atlantic forest of Paraná state it has been found to be the second most prevalent species. Its role as vector of Leishmania has not yet, as far as we know, been demonstrated. The highest values for the capture of $P S$. geniculatus occurred in April, as has also been recorded by Marcondes et al. (2001).

$P a$. lanei, the third most abundant species captured with automatic light traps and the fourth on Shannon traps, also captured biting humans, though it is commonly found in other areas of the Ribeira Valley (Gomes \& Galati 1987, 1989; Gomes et al. 1990), has had no role as a vector of Leishmania attributed to it.

Pi. fischeri was not captured biting humans in the PETAR, but was the fifth in abundance in the captures with automatic light traps and the third on the Shannon traps. Although its role as vector of Leishmania has not been conclusively established since it has not been found naturally infected by Leishmania, because of its high degree of anthropophily and its abundance in areas with transmission of cutaneous leishmaniasis it may be considered as a secondary vector (Rangel \& Lainson 2003).

In brief, comparing the results obtained in the two years
Table IV. Number of phlebotomines, by species and sex, captured on the black or white Shannon traps in the Santana nucleus - PETAR, from April 2001 to December 2002.

\begin{tabular}{|c|c|c|c|c|c|c|c|c|}
\hline \multirow[b]{2}{*}{ Species } & \multicolumn{2}{|c|}{ Black } & \multicolumn{2}{|c|}{ White } & \multicolumn{4}{|c|}{ Total } \\
\hline & M & $\mathrm{F}$ & M & $\mathrm{F}$ & M & F & MF & $\%$ \\
\hline Ev. edwardsi & - & 1 & - & - & - & 1 & 1 & 0.94 \\
\hline Lu. longipalpis & 1 & - & - & - & 1 & - & 1 & 0.94 \\
\hline Mi. petari & 1 & - & - & - & 1 & - & 1 & 0.94 \\
\hline Mg. migonei & - & - & - & 1 & - & 1 & 1 & 0.94 \\
\hline Ny. intermedia & 4 & 2 & - & - & 4 & 2 & 6 & 5.60 \\
\hline Ny. neivai & 1 & - & - & - & 1 & - & 1 & 0.94 \\
\hline Pa. lanei & - & 1 & - & 12 & - & 13 & 13 & 12.15 \\
\hline$P a$. sp. & - & 1 & - & - & - & 1 & 1 & 0.94 \\
\hline Pi. fischeri & - & 8 & 1 & 6 & 1 & 14 & 15 & 14.00 \\
\hline Pi. misionensis & - & 1 & - & - & - & 1 & 1 & 0.94 \\
\hline Pi. monticola & - & 7 & - & 2 & - & 9 & 9 & 8.41 \\
\hline Ps. ayrozai & 4 & 6 & - & 12 & 4 & 18 & 22 & 20.55 \\
\hline Ps. geniculatus & 8 & 21 & 2 & 4 & 10 & 25 & 35 & 32.71 \\
\hline Total & 19 & 48 & 3 & 37 & 22 & 85 & 107 & 100.00 \\
\hline
\end{tabular}

of captures in the two reserves, PETAR and PEI (the other sampled area of the ecological continuum of the Ribeira Valley), the mean number of insects collected with automatic traps in the former was significantly greater than that in the latter. Though the most abundant species captured in both areas present a close association with armadillos, in the PETAR, the known anthropophilic species, Ps. ayrozai, Ps. geniculatus, Ny. intermedia, Ny. neivai, Pi. fischeri, Mg. migonei and $\mathrm{Lu}$. longipalpis, were more numerous than in the PEI, the opposite occurred with Pi. monticola, also anthropophilic. Thus while a greater number of species may bother visitors to the PETAR, all of them are known to present nocturnal habits, while this last species also bites in the diurnal period. Among the species captured in the PETAR, Lu. longipalpis and those of the genus Nyssomyia call for special attention due to their respective involvement in the American visceral and cutaneous leishmaniases. Though the frequencies of these species were not very high in the preserved environments sampled, it is also necessary to investigate neighboring deforested areas with established human and domestic animal populations, in which these vectors may find more food sources as well as more adequate conditions for their development, with a consequent increase in the risk of transmission of these parasite diseases.

Acknowledgements. Our gratitude to the guide, Jânio Ribeiro de Andrade and to Dr. Ademir Galati who provided the necessary logistic support. Thanks are also due to Mr. Arthur Anthony Boorne for his correction of the English text. This project had financial support of FAPESP (00/06811-0) and the licence of IBAMA -SP (process n. 02027007000/2000-76).

\section{REFERENCES}

Aguiar, G. M. \& W. M. Medeiros. 2003. Distribuição regional e hábitats das espécies de flebotomíneos do Brasil, p. 207-255. In: E. F. Rangel \& R. Lainson (eds.). Flebotomíneos do Brasil. Rio de Janeiro, Fiocruz, $367 \mathrm{p}$.

Aguiar, G. M.; W. M. Medeiros; T. S. De Marco; S. C. Santos \& S. Gambardella. 1996. Ecologia dos flebotomíneos da Serra do Mar, Itaguaí, Estado do 
Rio de Janeiro, Brasil. I - A fauna flebotomínica e prevalência pelo local e tipo de captura (Diptera, Psychodidae, Phlebotominae). Cadernos de Saúde Pública 12: 195-206.

Aguiar, G. M.; M. L. Vilela; P. A. Schuback; T. Soucasaux \& A. C. R. Azevedo. 1985. Aspectos da ecologia dos flebótomos do Parque Nacional da Serra dos Órgãos, Rio de Janeiro. IV. Freqüência mensal em armadilhas luminosas (Diptera, Psychodidae, Phlebotominae). Memórias do Instituto Oswaldo Cruz 80: 465-482.

Andrade-Filho, J. D.; E. A. B. Galati \& A. L. Falcão. 2007. Nyssomyia intermedia (Lutz \& Neiva, 1912) and Nyssomyia neivai (Pinto, 1926) (Diptera: Psychodidae: Phlebotominae) geographical distribution and epidemiological importance. Memórias do Instituto Oswaldo Cruz 102: 481-487.

Aragão, H. B. 1922. Transmissão de leishmaniose no Brasil pelo Phlebotomus intermedius. Brasil Médico 36: 129-130.

Arrivillaga, J; J. P. Mutebi; H. Piñango; D. Norris; B. Alexander; M. D. Feliciangeli \& G. Lanzaro. 2003. The taxonomic status of genetically divergent populations of Lutzomyia longipalpis (Diptera: Psychodidae) based on the distribution of mitochondrial and isozyme variation. Journal of Medical Entomology 40: 615-627.

Auler, A. S. 2002. Karst areas in Brazil and the potential for major caves an overview. Boletin de la Sociedad Venezolana de Espeleología 36: 29-35.

Barretto, A. C.; J. A. Vexenat \& N. E. Peterson.1986. The susceptibility of wild caught sand flies to infection by a subspecies of Leishmania mexicana isolates from Proechmys iheringi denigratus (Rodentia, Echimyiidae). Memórias do Instituto Oswaldo Cruz 81: 235-236.

Boggiani, P. C.; O. J. Silva; A. L. D. Gesicki; E. A. B. Galati; L. O. Salles \& M. M. E. R. Lima. 2007. Definição de capacidade de carga turística das cavernas do monumento natural Gruta do Lago Azul (Bonito, MS). Geociências 26: 333-348 2007.

Brito M.; C. Casanova; L. M. Mascarini; D. M. V. Wanderley \& F. M. A. Corrêa. 2002. Phlebotominae (Diptera: Psychodidae) em área de transmissão de leishmanioses tegumentar americana no litoral norte do estado de São Paulo, Brasil. Revista da Sociedade Brasileira de Medicina Tropical 35: 421-437.

Brown, K. S. \& A. N. Ab' Saber. 1979. Ice-age refuges and evolution in the neotropics: correlation of paleoclimatological, geomorphological and pedological data with modern biological endemism. Paleoclimas 5: $1-30$.

Camargo-Neves, V. L.; A. C. Gomes \& J. L. F. Antunes. 2002. Correlação da presença de espécies de flebotomíneos (Diptera: Psychodidae) com registros de casos da leishmaniose tegumentar americana no Estado de São Paulo, Brasil. Revista da Sociedade Brasileira de Medicina Tropical 35: 299-306.

Carvalho, M. P.; C. H. G. Cezare; C. G. Costa; R. G. T. Cunha; S. S. Dornelles; M. S. Fialho; J. C. Guix; A. Hernándes; P. C. Lazarin; L. Lorens; M. Martín; E. Mateos; C. Miquel; L. M. Petroni; B. S. Pinto; K. Pisciotta K; C. Sanches; I. Oliveras \& A. Serra. 2002. Description of the study area, p. 27-50. In: E. Meteos; J. C. Guix; A. Serra \& K. Pisciotta (eds.) Censuses of Vertebrates in a Brazilian Atlantic Rainforest Area: The Paranapiacaba Fragment. Barcelona, Centre de Recursos de Biodiversitat Animal, Diviso III, Universitat de Barcelona, 217 p.

Casanova C.; R. C. Mayo; O. Rangel; L. M. Mascarini; M. G. Pignatti; E. A. B. Galati \& A. C. Gomes.1995. Natural Lutzomyia intermedia (Lutz \& Neiva) infection in the Valley of the Mogi Guaçú River, State of São Paulo, Brazil. Boletin de la Dirección de Malariología y Saneamiento Ambiental 35 (Supl 1): 77-84.

Ciiagro (Centro Integrado de Informações Agrometeorológicas) 2007. Resenha Agrometeorológica. Boletim Mensal < http://www.ciiagro.sp. gov.> (accessed 5 September 2007).

Cipa Group. 1999. Computer-aided Identification of Phlebotomine Sandflies of America. http://cipa.snv.jussieu.fr (accessed 12 September 2007).

Condino M. L. F.; S. M. P. Sampaio; L. F. Henriques; E. A. B. Galati; D. M. V. Wanderley \& F. M. A. Corrêa. 1998. Leishmaniose tegumentar americana: flebotomíneos de área de transmissão no município de Teodoro Sampaio, região sudoeste do estado de São Paulo, Brasil. Revista da Sociedade de Medicina Tropical 31: 355-360.

Cordoba-Lanus E.; M. L. De Grosso; J. E. Pinero; B. Valladares \& O. D. Salomón. 2006. natural infection of Lutzomyia neivai with Leishmania spp. in northwestwern Argentina. Acta Tropica 98: 1-5.

CVE (Centro de Vigilância Epidemiológica Alexandre Vranjac, Secretaria de Estado da Saúde de São Paulo) 2007. Leishmaniose Tegumentar Americana $<$ http://www.cve.saude.sp.gov.br/htm/zoo/lta_reg.htm $>$ (accessed 10 September 2007).

Dessen, B. E. M.; V. R. Eston; M. S. Silva; M. T. Temperini-Beck \& E. Trajano. 1980. Levantamento preliminar da fauna de cavernas de algumas regiões do Brasil. Ciência e Cultura 32: 714-725.

Domingos, M. F.; G. C. Carreri-Bruno; R. M. C. Ciaravolo; E. A. B. Galati; D. M. V. Wanderley \& F. M. A. Corrêa. 1998. Leishmaniose tegumentar americana: flebotomíneos de área de transmissão, no município de Pedro de Toledo, região sul do Estado de São Paulo. Revista da Sociedade Brasileira de Medicina Tropical 31: 425-432.

Forattini, O. P. 1973. Entomologia Médica. Phlebotominae. Leishmanioses. Bartonelose. São Paulo, Ed. Edgard Blücher Ltda, 658 p.

Forattini, O. P.; G. B. G. Pattoli; E. X. Rabello \& O. A. Ferreira. 1972. Infecção natural de flebotomíneos em foco enzoótico de leishmaniose no estado de São Paulo, Brasil. Revista de Saúde Pública 6: 431-433.

Forattini, O. P.; E. X. Rabello; O. P. Serra; M. D. Cotrim; E. A. B. Galati \& J. M. S. Barata. 1976. Observações sobre a transmissão da leishmaniose tegumentar no Estado de São Paulo, Brasil. Revista de Saúde Pública 10: $31-43$.

Forattini, O. P. \& M. R. Santos. 1952. Nota sobre infecção natural de Phlebotomus intermedius Lutz \& Neiva, 1912, por formas leptomonas, em um foco ativo de leishmaniose tegumentar americana. Arquivos de Higiene de São Paulo 17: 171-174.

Galati, E. A. B. 2003a. Morfologia e taxonomia. Classificação de Phlebotominae, p. 23-51. In: E. F. Rangel \& R. Lainson (eds.) Flebotomíneos do Brasil. Rio de Janeiro, Fiocruz, ii+367 p.

Galati, E. A. B. 2003b. Morfologia e taxonomia. Morfologia, terminologia de adultos e identificação dos táxons da América, p. 53-175. In: E. F. Rangel \& R. Lainson (eds.). Flebotomíneos do Brasil. Rio de Janeiro, Fiocruz, ii $+367 \mathrm{p}$.

Galati, E. A. B.; A. M. Marassá \& R. M. Gonçalves-Andrade. 2003. Micropygomyia (Sauromyia) petari, a new species of Phlebotominae (Diptera, Psychodidae) from Vale do Ribeira, São Paulo state, Brazil. Revista Brasileira de Entomologia 47: 455-459.

Galati, E. A. B.; A. M. Marassá; R. M. Gonçalves-Andrade; C. A. Consales \& E. F. M. Bueno. 2010. Phlebotomines (Diptera, Psychodidae) in the Ribeira Valley Spelological Province - 1. Parque Estadual Intervales, state of São Paulo, Brazil. Revista Brasileira de Entomologia 54 311-321.

Galati, E. A. B.; M. B. Fonseca \& A. M. Marassá. 2007. Review of the subgenus Migonemyia (Migonemyia) Galati 1995, with description of a new species Migonemyia vaniae. Memórias do Instituto Oswaldo Cruz 102: 605-615.

Galati, E. A. B.; V. L. B. Nunes; M. E. C. Dorval; G. Cristaldo: H. C. Rocha; R. M. Gonçalves-Andrade \& G. Naufel. 2001. Attractiveness of black Shannon trap for phlebotomines. Memórias do Instituto Oswaldo Cruz 96: 641-7.

Gomes, A. C. \& E. A. B. Galati. 1987. Aspectos ecológicos da leishmaniose tegumentar americana. 5. Estratificação da atividade espacial e estacional de Phlebotominae (Diptera, Psychodidae) em áreas de cultura agrícola da região do Vale do Ribeira, Estado de São Paulo, Brasil. Memórias do Instituto Oswaldo Cruz 82: 467-473.

Gomes, A. C. \& E. A. B. Galati. 1989. Aspectos ecológicos da leishmaniose tegumentar americana. 7. Capacidade vetorial flebotomínea em ambiente florestal primário do Sistema da Serra do Mar, região do Vale do Ribeira, Estado de São Paulo, Brasil. Revista de Saúde Pública 23: 136-142.

Gomes, A. C.; E. X. Rabello \& E. A. B. Galati. 1978. Flebotomíneos encontrados em galinheiros experimentais nos estados de São Paulo e Minas Gerais (Brasil) e algumas observações ecológicas. Revista de Saúde Pública 12: 403-7.

Gomes, A. C.; E. X. Rabello; J. L. Santos \& E. A. B. Galati. 1980. Aspectos ecológicos da leishmaniose tegumentar americana. I. Estudo experimental da freqüência de flebotomíneos a ecótopos artificiais com referência especial a Psychodopygus intermedius. Revista de Saúde Pública 14: 540-556.

Gomes, A. C.; E. X. Rabello; J. L. Santos \& E. A. B. Galati. 1982. Aspectos ecológicos da leishmaniose tegumentar americana. 2. Ecótopo artificial como abrigo de Psychodopygus intermedius e observações sobre a alimentação e reprodução sob influência de fatores físicos naturais Revista de Saúde Pública 16: 149-159.

Gomes, A. C.; E. X. Rabello; J. L. Santos \& E. A. B. Galati. 1983. Aspectos 
ecológicos da leishmaniose tegumentar americana. 3. Observações naturais sobre o ritmo diário da atividade de Psychodopygus intermedius em ambiente extraforestal. Revista de Saúde Pública 17: 23-30.

Gomes, A. C.; J. L. Santos \& E. A. B. Galati. 1986. Ecological aspects of American cutaneous leishmaniasis 4. Observations on the endophilic behavior of the sandfly and the vectorial role of Psychodopygus intermedius in the Ribeira Valley region of the São Paulo state. Revista de Saúde Pública 20: 280-287.

Gomes, A. C.; J. M. S. Barata; E. O. R. Silva \& E. A. B. Galati. 1989. Aspectos ecológicos da leishmaniose tegumentar americana. 6. Fauna flebotomínea de matas residuais situadas na região centro-nordeste do Estado de São Paulo, Brasil. Revista do Instituto de Medicina Tropical de São Paulo 31: 32-39.

Gomes, A. C.; S. G. Coutinho; G. V. Paim; S. M. O. Oliveira; E. A. B. Galati; M. P. Nunes; N. A. Capinzaiki; Y. I. Yamamoto \& P. Rotter. 1990. Aspectos ecológicos da leishmaniose tegumentar americana. 8. Avaliação da atividade enzoótica de Leishmania (Viannia) braziliensis, em ambiente florestal e peridomiciliar, Região do Vale do Ribeira, Estado de São Paulo, Brasil. Revista do Instituto de Medicina Tropical de São Paulo 32: 105-115.

Haddow, A. J. 1960. Studies on the biting-habits and medical importance of East African mosquitos in the genus Aedes. I. Subgenera Aedimorphus, Banksinella and Nunnius. Bulletin of Entomological Research 50: 759-779.

Hayek, L. A. C. \& M. A. Buzas. 1997. Surveying Natural Populations. New York, Columbia University Press, 563 p.

Karmann, I. \& J. A. Ferrari. 2002. Carste e Cavernas do Parque Estadual Turístico do Alto Ribeira (PETAR), SP -Sistemas de cavernas com paisagens subterrâneas únicas. p. 401-413. In: C. Schobbenhaus; D. A. Campos; E. T. Queiroz; M. Winge \& M. L. C. Berbert-Born (eds.) Sítios Geológicos e Paleontológicos do Brasil. 1. ed., Brasília, DNPM/ CPRM - Comissão Brasileira de Sítios Geológicos e Paleobiológicos (SIGEP), $554 \mathrm{p}$.

Lainson, R. \& J. J. Shaw. 2005. New World leishmaniasis, p. 313-349. In: F. E. G. Cox; J. P. Kreier \& D. Wakelin (eds.). Topley \& Wilson's Microbiology and Microbial Infections, Parasitology. $10^{\text {th }}$ ed., London, Arnold, $883 \mathrm{p}$.

Marcondes, C. B. 1996. A redescription of Lutzomyia (Nyssomyia) intermedia (Lutz \& Neiva, 1912), and resurrection of L. neivai (Pinto, 1926) (Diptera, Psychodidae, Phlebotominae). Memórias do Instituto Oswaldo Cruz 91: 457-462.

Marcondes, C. B. 2007. A proposal of generic and subgeneric abbreviations for phlebotomine sandflies (Diptera: Psychodidae: Phlebotominae) of the world. Entomological News 118: 351-356.

Marcondes, C. B.; A. L. Lozovei \& J. H. Vilela. 1998. Distribuição geográfica de flebotomíneos do complexo Lutzomyia intermedia (Lutz \& Neiva, 1912) (Diptera, Psychodidae). Revista da Sociedade de Medicina Tropical 31: $51-58$

Marcondes, C. B.; L. G. Santos-Neto \& A. L. Lozovei. 2001. Ecology of phlebotomine sandflies in Brazilian Atlantic forest. Revista da Sociedade de Medicina Tropical 34: 255-260.

Natal, D.; D. Marucci; I. M. Reis \& E. A. B. Galati.1991. Modificação da armadilha CDC com testes para coletas de flebotomíneos (Diptera). Revista Brasileira de Entomologia 35: 697-700.

Nimer, E. 1977. Geografia do Brasil - Região Sudeste. Rio de Janeiro, IBGE, $667 \mathrm{p}$.
Pinto, M. C.; D. H. Campbell-Lendrum; A. L. Lozovei; U. Teodoro \& C. R. Davies. 2001. Phlebotomine sandfly responses to carbon dioxide and human odour in the field. Medical and Veterinary Entomology 15: $132-139$.

Pita-Pereira D.; C. R. Alves; M. B. Souza; R. P. Brazil; A. L. Bertho; A. F. Barbosa \& C. C. Britto. 2005. Identification of naturally infected Lutzomyia intermedia and Lutzomyia migonei with Leishmania (Viannia) braziliensis in Rio de Janeiro (Brazil) revealed by PCR multiplex nonisotopic hybridization assay. Transactions of the Royal Society of Tropical and Medicine Hygiene 99: 905-913.

Poulson, T. L. \& W. B. White. 1969. The cave environment. Limestone caves provide unique natural laboratories for studying biological and geological processes. Science 165 971-981.

Rangel, E. F.; N. A. Souza; E. D. Wermelinger \& A. F. Barbosa. 1984. Infecção natural de Lutzomyia intermedia Lutz \& Neiva, 1912 em área endêmica de leishmaniose tegumentar no estado do Rio de Janeiro. Memórias do Instituto Oswaldo Cruz 79: 395-396.

Rangel, E. F. \& R. Lainson. 2003. Ecologia das leishmanioses: transmissores de leishmaniose tegumentar americana, p. 291-309. In: E. F. Rangel \& R. Lainson (eds.). Flebotomíneos do Brasil, Rio de Janeiro, Fiocruz, $367 \mathrm{p}$.

Roberts, D. R. \& B. P. His. 1979. An index of species abundance for use with mosquito surveillance data. Environmental Entomology 8: 1007-13.

Shaw, J.; A. T. Rosa; A. Souza \& A. C. Cruz. 2003. Flebotomíneos brasileiros como hospedeiros e vetores de determinadas espécies, p. 337-351. In: E. F. Rangel \& R. Lainson (eds.). Flebotomíneos do Brasil, Rio de Janeiro, Fiocruz, $367 \mathrm{p}$.

Sigrh (Sistema de Informações para Gerenciamento de Recursos Hídricos do Estado de São Paulo). 2007.http://www.sigrh.sp.gov.br/cgi-bin/bdhm. exe/procura (accessed 5 July /2007).

Sociedade Brasileira de Espeleologia. 2007. http://www.sbe.com.br/

Souza, N. A.; C. A. Andrade-Coelho; M. L. Vilela \& E. F. Rangel. 2001. The phlebotominae sand fly (Diptera: Psychodidae) fauna of two rain forest reserves in the state of Rio de Janeiro, Brazil. Memórias do Instituto Oswaldo Cruz 96: 319-324.

Souza, N. A.; C. A., Andrade Coelho; V. C. Silva; A. A. Peixoto \& E. F. Rangel. 2005. Moonlight and blood-feeding behaviour of Lutzomyia intermedia e Lutzomyia whitmani (Diptera: Psychodidae: Phlebotominae), vectors of American cutaneous leishmaniasis in Brazil. Memórias do Instituto Oswaldo Cruz 100: 39-42.

Taniguchi, H. H.; J. E. Tolezano; R. Larosa; R. C. Elias \& E. A. B. Galati. 2002. Observações ecológicas de flebotomíneos em área endêmica de leishmaniose tegumentar americana (LTA) no município de Eldorado, Vale do Ribeira, Estado de São Paulo, Brasil, 1996-1997. Sazonalidade e freqüência de L. ayrozai em diferentes ecótopos com animais sentinelas em ambiente florestado. Revista do Instituto Adolfo Lutz 61: $103-112$.

Vexenat, J. A.; A. C. Barretto; C. C. Cuba \& P. D. Marsden. 1986. Características epidemiológicas da leishmaniose tegumentar Americana em uma região endêmica do Estado da Bahia. III. Fauna flebotomínica. Memórias do Instituto Oswaldo Cruz 81: 293-301.

Young, D. G. \& M. A. Duncan. 1994. Guide to the identification and geographical distribution of Lutzomyia sandflies in Mexico, the West Indies, Central and South America (Diptera: Psychodidae). Memoirs of the American Entomological Institute 54: 1-881. 